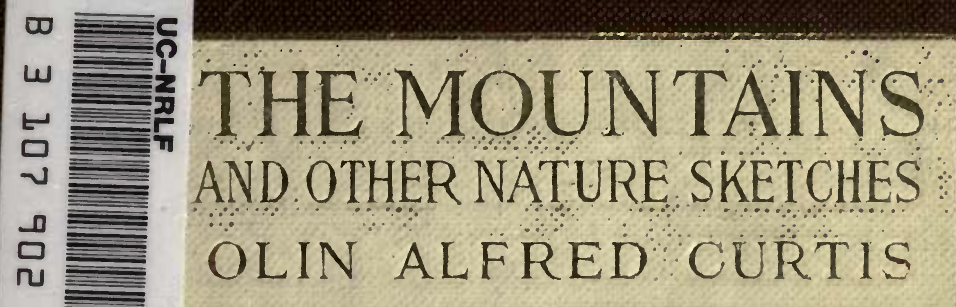




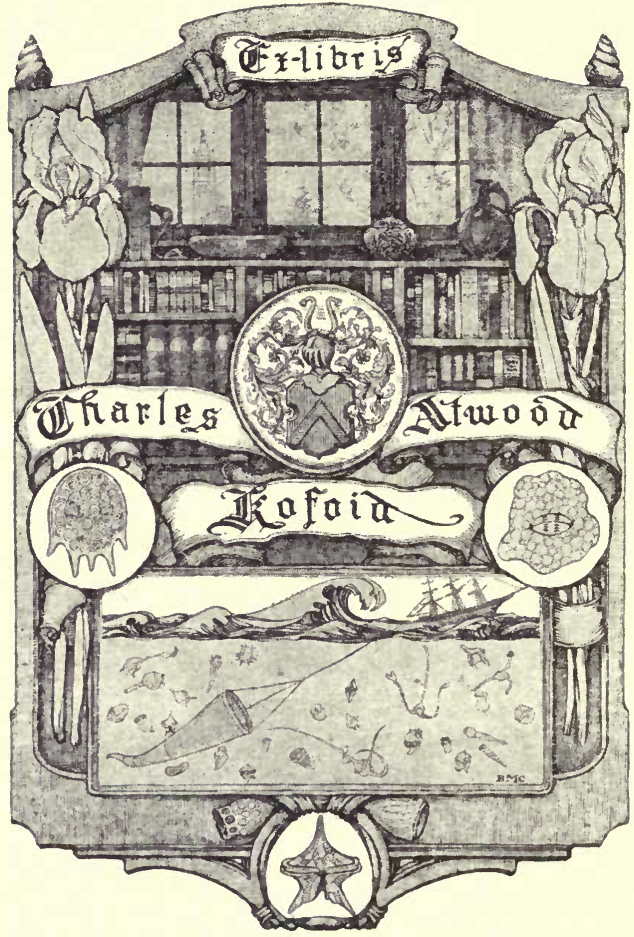


Bircholar, Arateney,

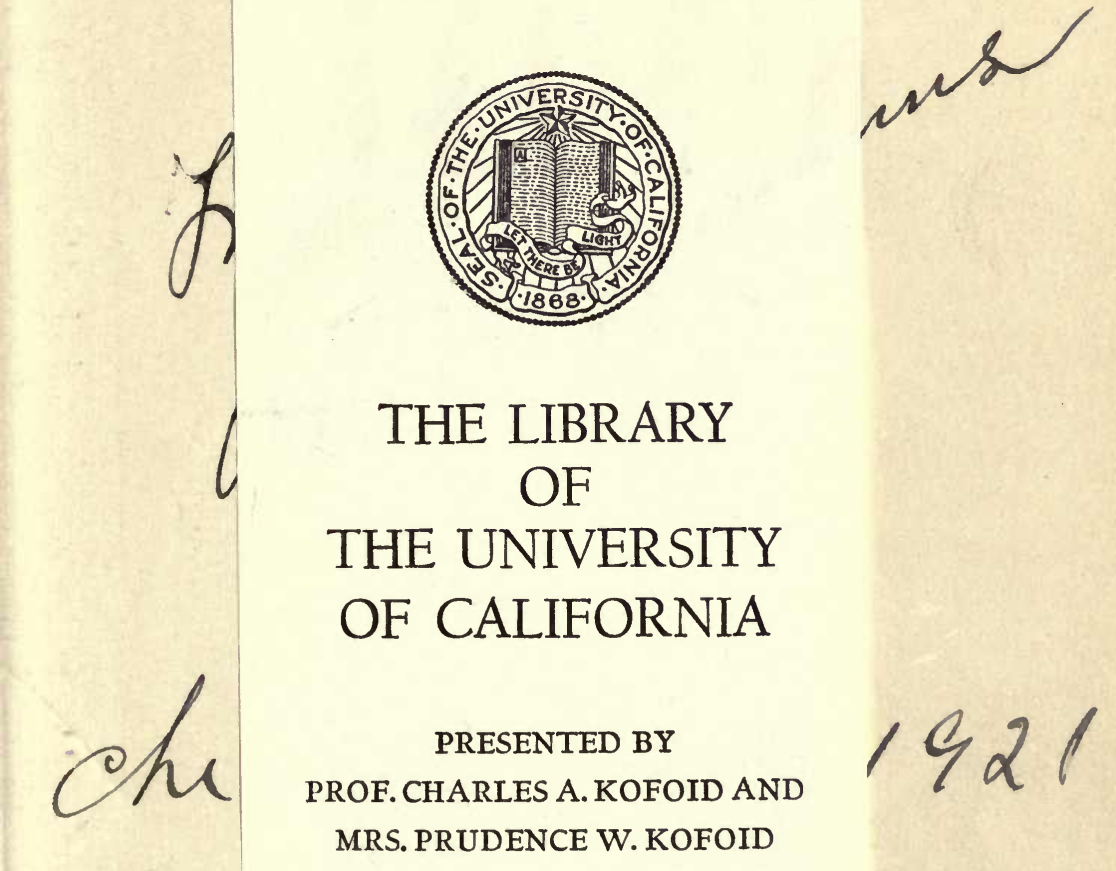






\section{BY THE SAME AUTHOR}

THE CHRISTIAN FAITH 



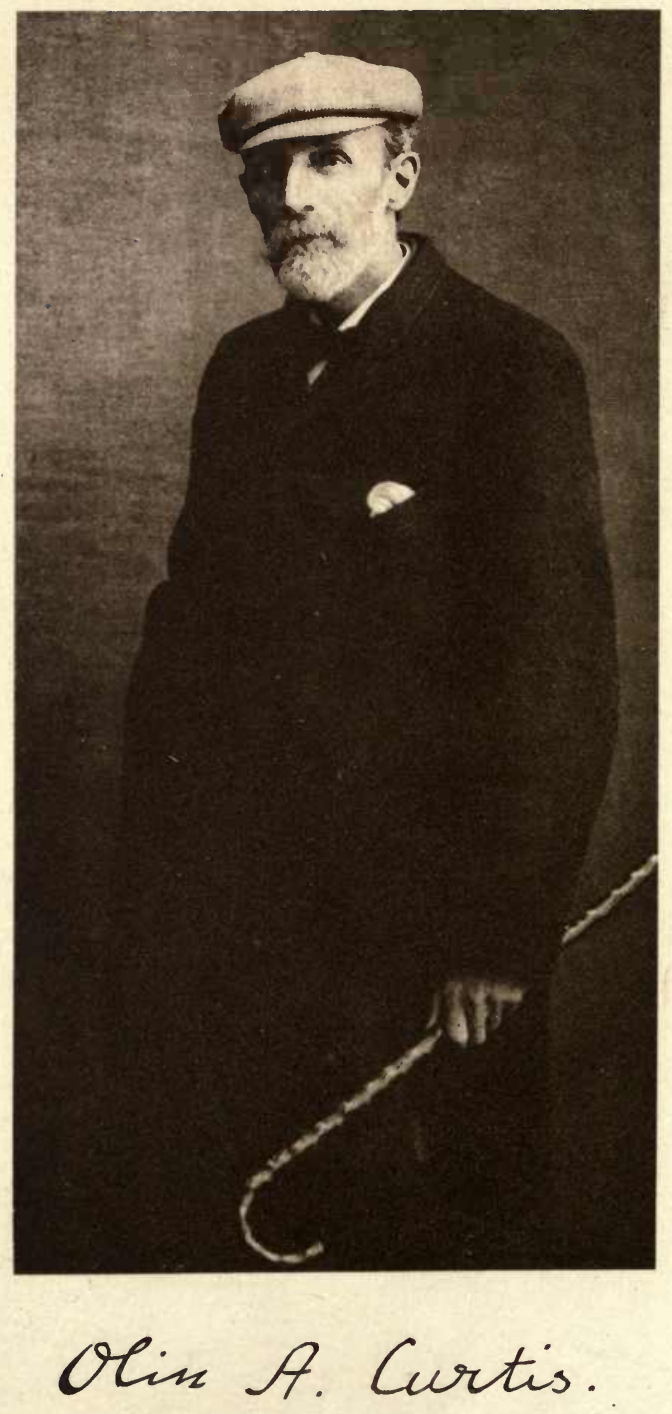




\title{
THE MOUNTAINS And Other Nature Sketches
}

\author{
By \\ OLIN ALFRED CURTIS
}

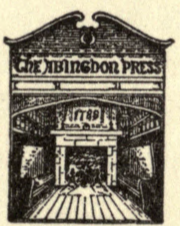

THE ABINGDON PRESS NEW YORK CINCINNATI 
Copyright, 1920, by

IDA GORHAM CURTIS

THIS EDITION

IS LIMITED TO

ONE THOUSAND COPIES,

OF WHICH THIS IS

No.220 


\section{CONTENTS}

CHAPTER

PAGE

FonEword .............. 7

I. The Mountains. A Series of STUDIES:

Ifirst tưp

The Mass of the Mountains ..... 11

Second Study

The Beauty of the Mountains ... 18

Ebird tudy

The Uplift of the Mountains.... 26

Jourth stuop

The Mrstic Tonic of the MounTAINS ............... 33

II. In the Mountains with the Hermit Thrush ................ 43

III. The Flight of Birds. Litrle Glimpses of a Large Matter. 61

IV. A Passing Word About Trees .... 77

V. In an Old Ouive Grove......... 89

VI. Treetops in Winter .......... 113

VII. JoHN................... 123

VIII. The Illumination of an Old Farm 139 



\section{FOREWORD}

7 "Nature Sketches," as their author called them, is in response to the many requests which came to him in the last few years of his life.

While the field study of birds and of the trees that were characteristic of any locality, was a recreation full of pleasure for him, back of all and above all, he felt the appeal of the mountains. The mountains satisfied him; they rested him.

More than twenty times he visited the "White Hills" of New Hampshire; sometimes returning to the scene of a former stay, often going to a new point from which to study them. He went among them, he went around them and to the tops of many of them. Other mountain regions claimed him from time to time; but this was his "mountain home."

This love of his for mountains was 
known to all who knew him. Never a summer passed without letters from students, and other friends in vacation lands, whose thoughts had turned to him when they saw "his" mountains.

The friends who tramped with him along country roads and through mountain paths have long remembered those days, for a walk with him could never be commonplace. It might more easily be an event.

The world of literature too was always hovering near him and from its store he often brought some beautiful expression fitting the scene before him.

It was from such days of freedom, and association with Nature in her many forms-whether rugged mountain or peaceful valley - that he came away renewed in body and spirit.

"The quiet of the fields and woods Sank deep into his soul."

Ida Gorham Curtis.

Leonia, New Jersey. 
I

\section{THE MOUNTAINS}

\section{A SERIES OF STUDIES}





\section{I}

\section{Jirst study}

\section{THE MASS OF THE MOUN- TAINS}

T $N$ any serious study of the mountains, 1 the feature first to be noted is their mass. This word "mass," though, has mere availability, it is not adequate. I looked through an entire book, Professor Tyndall's Glaciers of the Alps, in search for an adequate and suitable word, but I found none. It is allowable, therefore, to charge the word "mass" with a larger meaning.

By the mass of the mountains I mean, not their bare bulk, but their powerful bulk. An approach to the full meaning is inherent, I think, in the colloquialism: "It is a mighty big thing." The mountain-mass is both big and mighty. 
Just here, however, a fine touch of discrimination is necessary. The mass of the mountains does not evince dynamic quality, the mountain-power is not sensibly active. We do not expect the mountains to move, we simply expect them not to be moved. As a New England farmer said: "Those old fellows stay put." And the mountains stay in place, not as any unmolested bulk might stay in place, but as a great force stays in place when smaller powers are storming against it.

Of course, as a matter of scientific fact, the mountains are yielding and changing all the time. "Every mountain is being pulled down in the very process of its elevation." But as phenomena appealing to our senses, as cosmic poetry appealing to our imagination, and as spiritual symbol appealing to our inner craving for something abiding, the mountains, in some way, create for us the impression of potent immovability.

In Jefferson Highlands, New Hamp- 
shire, there is a mountain pasture where one can easily get, in vision, the whole mass of the majestic sweep of the Presidential Range. No other spot is there, not in the Tyrol, not even in Switzerland, where I have felt such a pressure of pure unmodified mountain-mass. The huge, looming bulk swells out and up, in such impressive cohesion, in such bulwark domination, that the very foundations of the world seem to be in sight. In this pasture, looking at that stupendous rampart, no man could call the mountains (actually said) "Vast, undigested heaps of stone."

Under Niagara Falls I was stimulated into a violent curiosity, and I wanted constantly to ask interesting questions of my guide; but here, before this mighty mass, I had no wish to speak, indeed, no wish for anything whatever. I was smitten into the silent rapture of an overwhelming awe.

It is this porwer-mass which makes it 
possible for the mountains to symbolize, for men, eternal stability. They look like something everlasting. Our natural and instant feeling is: "Only the Almighty Creator Himself can move them!" And precisely this feeling is, I judge, the poetic origin of the sublime passage in the book of Habakkuk, where the prophet declares:

"He stood, and measured the earth;

He beheld, and drove asunder the nations; And the eternal mountains were scattered; The everlasting hills did bow;

His goings were as of old.

\section{The Quiet of the Mountains}

This feature is an outcome of the first, but, for the sake of emphasis, it is here considered separately.

Several times, in my experience on the mountains, there has been a complete superficial quiet. I did not hear a rock slip or a fissure open wider or a cloud rend in the wind or a startled bird rustle in the underbrush. Once, in fact, it was so un- 
naturally silent that my ear could detect not even "the slender clarion of the unseen midge."

And, as to visible movement, there was just one exception to an apparently motionless surface of things, and that one exception was the "Arctic butterfly" (ceneis semidea), as, half-crawling, halfflying, it worked its tortuous passage over the bowlders, "like a two-inch fleck of gray-brown lichen that has suddenly become a spirit."

But this superficial quiet is not peculiar to the mountains, and, save in the mountain-woods, is not, I would say, often experienced on the mountains. On the contrary, the quiet which $I$ have in mind is peculiar to the mountains, for it is nothing less than the intrinsic stillness of the basal mass. I am wont to call it the quiet of the fundament.

In this connection there stands out in memory one mountain, "the sentinel of Franconia Notch"-rugged old La- 
fayette! How many times I have eagerly watched a storm gather and at last strike him in mad fury - the wind now more than a gale; the trees bending and breaking; the rain slanting into interminable sheets of pelting lead; the lightning plowing zigzag furrows of fire; the thunder crashing and booming with crag-tossed echoes like heavy gun-fire; the entire mountain-surface in titanic conflict. But not by an infinitesimal fraction of a point did old Lafayette move out of place. "The underbasing does not tremble." His massive fundament, his real mountain selfhood (so to speak), was as undisturbed as the soul of an apostle in hours of trouble. Had he been a person, with gift of rational speech, doubtless he would have said something like this: "We are annoyed on every side, yet not distressed."

This basal quiet of the mountains in large measure it is which makes them such agents of human healing. As one of large experience has said: "Every great 
mountain is a febrifuge." Not in this study can we take up the full psychology of the matter; it is worth while to say, though, that, to a responsive spirit, the mountains supply a needed symbol of repose. In all the turmoil of the world, in all the deadly struggle for existence, in all the noise of the machinery of our civilization, in all the welter of animal passion, they have what Professor Van Dyke happily terms "their aloofness." Thus, for weary men, the mountains may become, sometimes do become, precious places of peace, Nature's finest material tokens of that "peace of God which passeth all understanding." 


\section{Second Study}

\section{THE BEAUTY OF THE MOUN- TAINS}

T considering the beauty of the moun1 tains we should always begin with form. Structural form in a mountain has the kind of importance which architectural form has in a cathedral. Indeed, a study of the famous cathedrals, architecturally, would be an excellent preparation for the study of mountains.

Probably, in common estimate, the most beautiful mountainshape is the pyramidal (Mount Garfield), where, from one summit-point, the mass falls away sharply on all sides. In Sweetser's "Guide" there is a humorous reference to a mountainnative who, when questioned as to the 
beauty of the mountains in his region, answered: "Wal, yes, but if I'd had the sortin' of these hills I'd made 'em a little peakeder."

Once I myself had this naive preference for the mountain-pyramid, but now I discover a peculiar beauty in those along flowing lines which are the artistic outcome of ages of abrasion. For instance, take Mount Kinsman. What an exquisite skyline ("in cadence swinging like an ocean swell"), and especially is it exquisite over against a dark stretch of nimbus cloud! Here we have just the combination of massive base and outreaching lines and solemn color which, in this Franconia region, appealed to the sensitive, introspective genius of our most original writer in the realm of creative fancy-Nathaniel Hawthorne.

Mountain-form, though, is only the beginning of mountain-beauty. Thomas Starr King (called "the American Ruskin," although, at times, he is more nearly 
akin to De Saussure), in The White Hills, says, "It is not so much the forms, in their dimensions, proportions, and arrangements, which produce the effect of beauty and sublimity, as the quality, variety, and harmony of the color which overlay and imbue them."

And, if I may dare to rely upon my own mountain-experience, I must add that, in mountain-scenery, the most effective thing, beauty alone being considered, is the ever-shifting pattern of the colorscheme.

From one point, in the Bernese Oberland, often $I$ have seen four ranges of mountains and foothills, and every range with a dominant color-green, brown, blue, white. And still, in every case, not excepting even the last, the dominating color was subject to color-invasions, sudden or gradual; or to delicate color-shadings; or to minute color-lineations; or to splendid color-illuminations. Thus there was in action a sort of huge mountain- 
kaleidoscope which continually was changing the mosaic of its pattern.

When carefully investigated, this instability of color-scheme is found to be a matter of exceedingly complicated causation. The changes are brought about, or influenced anyway, by such things even as the angularity of the rocks, the texture of the bark of trees, the drifting and transformations of clouds, the depth to which the light at a given time can penetrate a chasm, and also by the size and contour and rock-structure of the mountain itself. Of course the one supreme color-magician is the sun, and yet moon and stars are the agents in some of the most romantic enchantments of mountainbeauty.

There are ranges, like the Great Smoky Mountains, which have been reported, now and again, as having a fixed colorscheme; but, after a patient test, convincingly it appears that such a scheme does not exist. The reports are due, doubtless, 
to the extreme moderation of the shifts in color-combination.

While form and color are the items which the mountains contribute to beauty, these items, it should be noted, often combine into a larger beauty by reason of the setting in which the peak or range is placed. In this mountain-frame there are many potent features. First, there is the overarching sky, which always is doing some gloriously beautiful thing to a mountain. Then there are settings where meadow, or forest, or lake, or river, or river-valley plays an important part. Then there are settings where winding roads and picturesque villages seem to enhance the mountain-beauty. Then there is the combination-frame, where many things artistically interact, as, for example, when we view Mount Pisgah from Asheville, or the White Mountains from Sugar Hill. This last view has a combined total of mountain-beauty which, in a period of more than twenty years, has 


\section{THE BEAUTY}

never lost for me an atom of its unique charm.

The beautiful mountain-pictures which remain clearly in memory are too many for description in this study, but, among them, there is one which was so entrancingly beautiful that I am unwilling to pass it by. I will try to paint the scene precisely as it comes to me now after six years.

It was early in June, and I was at Gunten, on the eastern side of the Lake of Thun, which is, according to Leslie Stephen, "the loveliest of all conceivable lakes." I had chosen a position where there was the widest possible view of that matchless group of peaks which is named the Blümlisalp. It was a few minutes before sunset, and I was alone, watching the spreading silver of the light as it played in soft, chasing witchery over the vast fields of snow.

Suddenly, just out of my line of vision, the sun dropped behind the curved edge 
of one of the "horns," and there was a suggestion of darkness. It was not exactly twilight; it was, rather, an allusive warning that twilight might be expected very soon. This suggestion of darkness lasted, I would say, less than twenty seconds, and then the highest peak in the group turned to gold. As I remember the color, it was not yellow, not orange, not even "old gold," it was lustrous like a gold coin just from the mint. Almost instantly this shining gold spread outward and downward until it entirely covered four peaks. To me, gazing there in a kind of apocalyptic mood, it was an Alpine reminder of Saint John's "four horns of the golden altar which is before God."

But, before my eyes were adjusted to the splendor, the gold turned into a pink as delicate and rich and brilliant as is the pink of a perfect Killarney rose. This color remained hardly at all before it deepened into a shade which was almost 
carmine, only it was translucent, as much so as is a roseate coal of burning driftwood.

This stage of the "afterglow" lasted long enough for me to call the people in the pension, say eight or ten minutes, then the color slowly faded into a blushing pearl; then, more slowly, into a ghostly, vaporous white, which became fainter and fainter until utterly lost in the gloaming.

Now the village-lights of Spiez, across the lake, began to appear over against the vague, mysterious night-masses of the mountains. 


\section{Third Studp}

\section{THE UPLIFT OF THE MOUN- TAINS}

DWARD EVERETT HALE, as
the anecdote is told, was in Chicago, walking along the lake-front with a Western friend. The great lake was "working up a storm," and, as the waves came racing in, the friend confidently said, "Quite the same thing to you as your ocean at home, isn't it, Doctor?"

"No, not at all," was the instant answer; "it is not big enough."

"But," insisted the Westerner, "practically it must be about the same, for you do not see the Michigan shore."

"True," replied Dr. Hale, "I do not see the other shore, but I know and feel that it is just over there?" 
The supreme characteristic of the ocean, at least in its higher range of influence, is that it is "big enough." For it is this spaciousness (in continuous extension) which enables the ocean to become for men a usable sign of measureless distance. In the terse saying of Julius $H$. Ward, "It calls forth the feeling of endless reach."

Right here we come upon what, to some students of nature anyway, is the chief difference (æsthetic difference) between the sea and the mountains. It lies in the direction of the reach. In the one case the reach is out over the earth; in the other case the reach is up into the sky. Suitably we might call one the terrestrial outreach; the other the celestial uplift.

Do we appreciate the value of an upward direction in space? Do we understand "the philosophy of the steeple"? The gist of the matter can be brought out and made emphatic, perhaps, in this way; imagine a large, wild prairie, level-lined, 


\section{THE MOUNTAINS}

no trees, not even a cottonwood, and no visible boundary save the horizon. Think of this landscape, monotonously flat, until its flatness becomes a mental burden. Now imagine, suddenly, in the center of this flat prairie, a tree or two of the towering kind, say Blue Spruces, having an upthrust of from eighty to one hundred feet. ... Is the contrast in landscapequality not apparent? Is there not a new and more poetic appeal to our sensibility? And has not this appeal even a spiritual tendency? Do the tree-steeples not entice us to look and think and feel, up and away from the low-lying tangle of grass and prairie weeds?

The trees, as Wordsworth, with his usual finality, says, "connect the landscape with the quiet of the sky."

Not yet, though, have we captured the full mountain-peculiarity. The uplift of the mountains is much more than a steepleupthrust. We must add mass. The mountain-mass is lifted up into the sky. 
And the result is a most stupendous thing, namely, the looming of the mountains.

At this point it is a relief to quote from John C. Van Dyke. In his recent book on The Mountain (Scribners, April, 1916), he says: "Moreover, there is still another quality that comes with the mighty uplift - the quality of looming in the peak. At times the whole peak seems to ride the blue sky, and comes looming forward and upward above us."

\section{The Junghrau}

For years I had, and in large measure, valued the uplift of the mountains, but its profound meaning, the astounding spiritual poetry of it all, was not revealed to me until, one fortunate day, I saw the Jungfrau, after a long rain, emerge.

John Ruskin, in Modern Painters, says, "It would be very grand if one ever saw a great mountain peak breaking through the domed shoulders of a true cumulus; 
but this I have never seen." Neither have I, exactly, for the cumulus was not present; but what I did see was the queenliest of all the Swiss mountains breaking through a huge mass of mist. And this mass of mist was not merely huge, it was extremely beautiful as well-in its own fashion, it was as beautiful as any cumulus cloud could possibly be. Beginning at the edge of the lake itself, the lower part of the mass, more than half of it, was grayish blue with diagonal, ragged bands of mottled green. This lower part, this mist-base, if I may so consider it, extended upward narroroly, and, with a serrated border, was joined to a pearlgray mass, which seemed to hold lurking shadows. Out of this pearly-gray mass there emerged, slowly and weirdly, the pure white summit of the Jungfrau.

In some secret play of nature's magic this slow and silent emergence of the peak from the mass of clinging mist seemed to accentuate the upthrust, and also dramat- 
ically to magnify the looming of the mountain. For the eye the Jungfrau now filled the sky; for the imagination verily she occupied universal space!

It is this uplift of the mountains, or, in precise detail, it is the upthrust and looming together, as related to the ever-changing sky, which creates the so-called "mystery of the mountains." Like all the larger poetic conceptions, this "mystery" is evasive, not easily defined in terms of practical speech. But something more or less helpful can be said. As I understand the nature-poets, they believe that the mountains, especially the loftier and more rugged peaks, do sometimes give to perfectly responsive souls a richly open and sensitive mood. And to such souls, in such a mood, the splendid summits, now lifted into space-dominion, are intimating symbols of spiritual verities away beyond their powerful bulk.

The real worth of this poetic phase of transcendental philosophy I may find, 
in another connection, a chance to estimate; here my only purpose is to present the matter. I should, however, present it fairly, and I want to present it generously. Allow me, therefore, to finish this study by trying to gather up the belief in a sympathetic paraphrase:

There is a supernature. There is a realm beyond all material things. At the cosmic edge of this realm stand the mighty mountains. They are sentinels. More than that, they are heralds incognito. And they have a message. At propitious times-perhaps when the upper spaces are blue and billowing with cumulus clouds; perhaps when the peaks are loyal in purple of infinite depth; perhaps when they turn into the lavender pinnacles of a city of dreams; perhaps when they become solemn and sublime under the cold stars - at propitious times these mighty heralds speak to those having ears to hear, saying: "This rway, $B e$ loved, to a finer world!" 


\section{Jourth study}

\section{THE MYSTIC TONIC OF THE MOUNTAINS}

READING recently a tribal history R of the Navajo Indians, "the American Bedouins," I discovered that their religious beliefs are curiously entangled with mountains.

According to Navajo tradition, "the First-Man and First-Woman" were compelled, by reason of a deluge in their "underworld," to come to "our upper-world." As their only way to climb up was through "a hollow reed," they could carry as baggage only the one most precious thing, and this one most precious thing was, they quickly decided, a measure of earth from the loved mountains of their old home. As soon as "our upper-world" was safely reached, the measure of earth 
was used to form some new mountains, for memorial markings of "NavajoLand"; and around one of these memorial mountains, the central one, the Navajos began their existence as a tribe.

Naturally, therefore, the mountains in "Navajo-Land" play an important part in the tribal life; and, as naturally, they are regarded as peculiarly sacred. There are "mountain hymns" which, in a solemn ritual service, are chanted, with the eyes either closed or fixed in an ecstatic stare. A thrilling scene even to-day it is, when, after an all-night ceremony, the entire assembly, at the first sign of morning, begins to chant with weird intonation a hymn to the sacred mountains.

To these Navajo Indians the singing of these mountain hymns is more than a ritualistic form, for they deem it an exercise spiritually potent as to character and destiny. To show this, I will quote a short passage from the tribal history: "When a man sings of the mountain, then, 
through the singing, his spirit goes to the holy place, beyond the mountain, and he himself becomes, like the mountain, pure and holy, living eternally, forever blessed."

\section{A Navajo Mountain Chant}

As a matter of unusual interest, I will give, both in the original and in a translation by Natalie Curtis, one of these Navajo mountain chants:

\section{DSICHL BIYIN}

Piki yo-ye!

Dsichl-nantal,

Piki yo-ye,

Sa-a narai,

Piki yo-ye,

Bike hozhoni,

Piki yo-ye,

Tsoya shich ni-la.

Piki yo-ye!
MOUNTAIN HYMN

Thither go I!

Chief of all Mountains,

Thither go I,

Living forever,

Thither go I,

Blessings bestowing,

Thither go I,

Calling me "Son my Son."

Thither go I!

In this Navajo instance there is first apparent that myth-tendency which we so constantly find when we examine natural religious phenomena; but, under the myth, and coloring the myth, there is, as 
I catch the deeper spirit of the fantastic story, an intense mountain-regard, a real heart-bearing toward the mountains. These Navajos love the mountains and idealize the mountains and respond to all the intimations of the mountains. Indeed, the response of these Indians is not essentially unlike the transcendental response made by our modern mountaininterpreters to the mountains in "their mystery." This point could be proven, I think, by wide-range quotation and searching analysis, taking as material, such prose as Ward's chapter on "The Glory of Mount Washington," and such poetry as the Chamouni "Hymn" by Samuel Taylor Coleridge.

Now an important question springs up, namely, "What is the true meaning of all this mountain-enthusiasm?"

My own answer, after long consideration of the question and longer experience with the mountains, can be stated briefly in this way: Men have, beyond their per- 
sonal life, what for convenience we may call their cosmic life. Many interesting phases of this life have been discovered, and exploited too, by the modern students of the subconscious; but the cosmic life is vaster than the present surmise of any psychologist. One thing, however, is clear enough - in this cosmic life men are subject to currents of influence which are much more subtle than are any mental effects. The whole matter is bound up, I am convinced, in the fundamental fashion in which the Bible uses the term "heart." This peculiar influence, profounder than the intellectual process, may be fittingly regarded as a mystic stress having force only with man's individual center, or "the heart."

To illustrate: The first time I ever heard one of Sebastian Bach's great fugues, I did not comprehend its musical significance, did not understand its spiritual intention, could not tell in any degree what the composer was trying to do. I 
was like the ranchman who said, at a Theodore Thomas symphony concert, "This is a big place, but I don't just know the name of it." But the mighty fugue did not require mental comprehension on my part. It penetrated and invigorated the very center of manhood. I was quite another man, and for hours afterward my work, even the monotonous drudgery of my work, was done easily and rejoicingly.

The mountains are the mighty Bachfugues of nature. Far beyond their scientific import, they reach men and refresh men and comfort men and enlarge men and ennoble men. And so I dare to insist that there is such a thing as "the mystic tonic of the mountains."

This mystic tonic is effective ultimately at several points:

\section{Sensibilitity}

Here imagination is reanimated. The old deadness disappears, the old ennui disappears, the old conventional pose dis- 
appears, the old superiority to natural emotion disappears. Life once more is fresh and vital and immense.

No man can long fellowship with the mountains and not become at heart a child again, with a world of wonder all about him, and shy beauties at every turn like Trailing Arbutus in the mountain-woods.

\section{Moral Life}

At once, it should be strongly affirmed, against a certain trend more or less noticeable in mountain-literature, that the mountains do not create, do not even tend to create, moral concern. But when a man is moral centrally, when he really means righteously, then the mountains may gradually adorn his moral life with finer integrities and larger simplicities of conduct.

Mountain-people are, as I have usually found them, truthful, frank, and courageous; and never are they artificial. They 
have what one of the more robust of modern poets calls "the primal sanities."

\section{Religious Life}

Several times, in these studies, it has been practically important to take a connected thing and treat it with a solitary emphasis. And now again it is wise to use this somewhat arbitary method. Still, while the religious appeal of the mountains is connected with a number of mountain-features and effects, the largest, perhaps the culminating force of the appeal is that powerful influence which I have named "the mystic tonic of the mountains."

As with the moral life, so a word of caution is needful here. Rigidly speaking, there is no "religious message of the mountains." Not even in the slightest measure can they rightly take the place of the New Testament, for they supply no redemptional message whatsoever. As 
to the Old Testament, the situation is only a little better. The mountains, like any other part of the natural world, do furnish the material for a theistic inference; but they do not supply any communication from a personal God to sinful men under the moral law. This much, however, we may grant: To one who already believes in a personal Creator, as the psalmist believed in Jehovah, the mountains, like the heavens, "declare the glory of God."

Further: The mountains do not create religious faith, or even alone establish such a faith. John Ruskin tells us that the mountains "purify faith." Allowable possibly; but I prefer to say that the mountains invigorate faith. They make faith more glowingly vital and more commanding in consciousness. On the summits of great mountains, filled with their penetrating spirit, it is easier to actualize religious things - easier to lay hold of the unseen, easier to pray triumphantly, easier 
to feel certain of God's providence, easier to hate "the garish day," easier to be humble and thankful and generous, easier to be a Christian optimist.

Already I have said that the mountains are symbols of repose-they are much more than that, for they help us fully to use the symbols, and thus possibly to get that quick sense of our Lord's presence which quiets the anxious soul into a blessed, thrice-blessed trust.

"Cradled and rocked by wind and cloud, Safe pillowed on the summit proud, Steadied by that encircling arm Which holds the universe from harm, I knew the Lord my soul would keep, Among his mountain-tops asleep." 


\section{II}

\section{IN THE MOUNTAINS WITH THE HERMIT THRUSH}





\section{IN THE MOUNTAINS WITH THE HERMIT THRUSH}

\section{THAT the hermit thrush has not been 1 awarded the supremacy among the} singers of the bird-world is probably due to the difficulty usually found in hearing the bird's complete song. I say complete song; for it is easy enough, on a July evening, to walk out a half mile from a mountain hotel, in northern New England, and, while discussing the last game of golf, catch certain insistent, far-coming fragments of the song. Such fragments are worth a long journey, but to hear these is not to hear the whole song in its astonishing variety of delicate and intricate cadence. For this utter hearing of the song one needs to be near enough to separate definitely every phrase, yes, even to seize surely every vibrating note 
of every phrase. Inasmuch as this thrush, unlike our wood thrush in New Jersey, is extremely shy, has a gift for securing privacy and has also the weird arts of a ventriloquist, it is ofttimes a laborious matter to locate him, and then closely to approach him, and then to keep him unaware of your presence. A snap of a twig, a clumsy shifting of position, or a moment's labored breathing, and there is a sudden silence, a silence so emptying that it verily "leaves a hole in the woods." Perfectly to hear a hermit thrush I have worked harder than ever I did to climb a mountain. I have crawled through long tangles of underbrush, or patches of wild raspberry bushes, until I was dripping like a larch in the rain; then $I$ have lain on the ground as flat as an Indian "when he listens to hear the grasses grow"-all this effort to hear a dozen complete phrases woven together in the bird's peculiar manner. But what does a man care for sweat and scratches and wet garments and aching 
back if only he can hear a supreme song just as God made it?

Admitting that my testimony is not very significant (for I am neither a naturalist nor a musician), yet I want to give it, because I want to help those who are trying to make our supreme American songster more widely known. All enthusiastic testimony attracts attention to the bird. Many of the most famous bird singers I have heard, my list including the wood thrush, the European nightingale, the veery, and that splendid but most unappreciated bird, the Western lark; but the hermit thrush alone reaches my deeper manhood and influences me profoundly. In trying to describe the effect upon me of the hermit's song I hardly know what to say. Perhaps, though, the ultimate effect may be suggested in this way: If Schumann's "Träumerei" could hold fast its dreamy reminiscence and still take on hope, say such a glowing hope as so often appears in some of Bach's mighty 
Fugues, the combination would, I think, affect me precisely as does the finished song of the hermit thrush. I become like a man sitting in the gloaming, reminiscently dreaming, and yet feeling a rich hope that the dawn will at last break over the tops of the mountains!

To reenforce my testimony, I will quote from Schuyler Mathews. In his Field Book of Wild Birds and Their Music, first published in 1904, he furnishes musical notations made by himself, excepting those of the nightingale, which are transcriptions from Lescuyer and Athanasius Kircher. Based upon these exact notations, the author makes various comments, many of them both striking and illuminating. From these I will quote some of the most important portions:

The song of the hermit thrush is the grand climax of all bird music; it is unquestionably so far removed from all the rest of the wildwood singer's accomplishment that vaunted comparisons are invidious and wholly out of 
place. Still, it is necessary to show the nature of this superb songster's preeminence, and that can only be done by comparing his style with that of other birds. ... In the vales of Tuscany, Italy, one of the best places in Europe to hear the nightingale sing (possibly excepting the banks of the Volga, in Russia), there is ample opportunity to listen to the exquisite trills and solemn overtones of that famous bird, but an experienced ear will not discover in the song anything like the melody of the hermit thrush. ... There is nothing the wood thrush can do which will compare with a performance like this. I am sorry to disagree with the opinions of several writers on ornithology who find certain restrictions in the hermit's song, and think the notes are not remarkable for variety or volume, but it seems to me the magnitude of this thrush's melodic ability, not to speak of his brilliant execution, is beyond the conception of any one until he devotes at least three or four seasons to a studied analysis of the music. Some of the notes possess sufficient volume to be distinctly heard at a distance of a quarter of a mile, yet unless one is within thirty feet, or less, of the singer, it is impossible to catch the tout-ensemble of the song, or to gauge the extent of its melodic variety. 
There is an immense contrast in the dynamics of the song; it ranges from $p p$ to $f f$; there is nothing of this kind which characterizes the wood thrush's music. Also, there is a remarkable, mysterious overtone, purely harmonic and ventriloquistic in quality, which at times dominates the cadenza of the song and holds the listener in rapt surprise!... Yes, the tones are silver-burnished silver, and sweeter far than those of any instrument created by the hand of man!

During the first six weeks of my vacation (exactly stated, all of July and the first ten days of August) I had a most noteworthy experience with the hermit thrush. In the summer of 1907 I did what I could to become acquainted with the songster, going out in several directions from Littleton, New Hampshire, and my success was sufficient to create in me a determination to know more thoroughly this "bird of genius." Possibly this determination has been kept in force by an abiding ambition, which I have, to master and appreciate everything pecu- 
liarly American. In any case, there was chosen for our vacation this summer the very fastness of the hermit's territory (Franconia, New Hampshire), and our reward came steadily and generously for forty-one days. Once I found his nest; many times I saw him, five times with the distance and light so favorable that the rufous or reddish brown of his tail was very noticeable; every day excepting two (wet and cold), I heard him sing; one hundred and fifty times, perhaps; in ten different woods; as early as four o'clock in the morning and as late as eight at night. The details of this entire experience are too many for this article; but I can write somewhat closely concerning one thrush-for convenience let us call him Dulcet. This remarkable singer I first heard early in July (the sixth, I think), and I remember every stage of that exciting chase, exceedingly dubious until at last the bird flew into a clearing where I saw him distinctly, only eight or 
ten feet away, sitting on the dead branch of a young maple.

This clearing itself is so beautiful and fitting as to merit a brief description. It was made years enough ago so that there are no stumps. The ground is now covered with a maze of ferns (at least six kinds), meadow-sweet, steeple-bush, and goldenrod. Here and there, half buried among the larger ferns, are bowlders, just as nature dropped them ages ago in some tremendous glacial movement. On three sides the clearing is bounded by forest, with all sorts of trees from the tremulous poplar to the lordly spruce. Beyond the forest, to the north, is the hill which the natives have well named "Break-Neck Hill"; and over the western shoulder of this hill there is visible what I surmise to be a portion of Dalton Mountain. Toward the south, where the clearing is not forest bounded, one notices the rise which is finally to become "Sugar Hill" -as picturesque a spot as there is on 
earth, my soul has more than once affirmed. Over this rise, and somewhat to the west, Mount Kinsman begins to reach and reach toward Franconia Notch; but Mount Cannon completes the task with his mighty bulwark and the "Great Stone Face," which seems expectantly to await some great event in the coming centuries! Could a poet conceive of a more fitting place in which to hear the song of the hermit thrush?

Sitting on a bowlder in this clearing, I have heard as many as five hermit thrushes all singing at the same time; and it was quite a common experience to hear a duet, in the early evening, the two birds answering each other from the opposite edges of the woods, their song sounding out over the clearing like a cathedral antiphon. With such an opportunity for comparison as this clearing afforded, it soon became evident that every hermit sings a song of individual peculiarity. Indeed, the differences are as marked as are the features 
which the birds have in common. And it also became evident that Dulcet's voice was the richest, the most flexible, the most powerful, and the most confident. And he acted as if he were conscious of his superiority; for he would often violate the modest habit of the hermit thrush, gradually making his way from limb to limb, until he had reached the very top of the tallest tree; and in this lofty place he would dominate the entire clearing with entrancing melody for a long time. On one memorable occasion, indeed, he sang in this manner for about three quarters of an hour. The precise facts are these: For some time he had been singing, say thirty feet from the ground, when it occurred to me to time his song. After I looked at my watch, he sang twelve minutes without moving; then he flew (between two phrases of his song) certainly as much as twenty feet higher, and lighted on a dead branch which projected out over the clearing; here, from this 


\section{THE HERMIT 'THRUSH 55}

highest place, he sang without a break for twenty-six minutes, moving twice, and then only to turn around.

Looking over my notes I find that I heard Dulcet twenty-two times, and as much as six solid hours in all. Thus I had a chance to make a careful study of his song. In his song there are three basal phrases. First, there is a shrill phrase, where the bird steadily climbs until his voice goes to pieces "somewhere around G sharp, twenty octaves higher than the limit of the piano!" At first, this shrill phrase is amusing, but as one comes to relate it to the total song he perceives that a valuable element of great contrast is contributed. Second, there is a veery phrase. This reminds one of the veery's wild song, for it sounds like a ringing voice blown windingly down through a silver tube. Third, there is a contralto phrase. This phrase is given by Dulcet in an exceedingly peculiar manner, and I cannot furnish even a suggestion of what 
56

\section{THE MOUN'TAINS}

it is like. Again and again after this contralto phrase I have exclaimed, "There can be no sweeter sound this side of heaven." Nor is this all, for every phrase is given by Dulcet with two, and infrequently with three modifications; and yet all these phrases are wrought into one harmonious song-structure. And there is still one important feature to be noted, and this feature is true in a measure of every hermit thrush. The first note of every phrase is held, not an instant, but the ghost of an instant, and this suggestion of a pause wonderfully quiets the strong tide of the song and makes the total effect meditative.

Several times I made an exact record of Dulcet's song, to find out whether there was any law as to the order of singing the phrases. Here is a part of one of the records, $\mathrm{S}$ standing for the shrill phrase, $\mathrm{V}$ for the veery phrase, and $\mathrm{C}$ for the contralto phrase, to be read always from S downward: 
$\begin{array}{lllllllll}(1-S & S & S & S & S & S & S & S & S \\ (2-V & C & V & V & V & C & V & & V \\ (3-C & & C & C & C & V & C & & C \\ (4-C & & & C & V & & & & V \\ (5- & & & & & & & & V\end{array}$

After much study I decided that there was no law discoverable; the order of the phrases always seemed to depend upon the whim of the bird. But this does not, even in the smallest way, indicate any action beyond the automatic. The whims of animal life are all associational.

The last time I heard Dulcet (or any hermit thrush) was on the tenth day of August. For weeks the bird world had been gradually becoming quiet. First, the bobolinks suddenly stopped the tinkling outpouring of their haphazard ecstasy; then, on the tenth day of July, well on toward eight o'clock at night, the last song of the veery came weirdly swelling out of the nearest woods. This final veery song seemed to be a selah-signal to the whole chorus, and one by one the singers obeyed. How well I remember 
when we first missed, in the early morning, the martial whistle of the whitethroated sparrow! Then there were days when, on a long tramp, I did not hear a warbler, not even a redstart, or a Maryland yellow-throat; and I would return home pleased even to find a red-eyed vireo preaching his repetitious sermon high up in a rock maple. Worst of all, toward the end of July, there were unmistakable signs that the hermit thrush was beginning to think of the Gulf of Mexico; for he would make long pauses, or fly long distances between fragments of song, or leave phrase after phrase unfinished, or omit his late afternoon song altogether.

Fully realizing the dubiousness of the situation, yet I decided to make a serious effort to hear Dulcet once more. So Monday evening (as I have said, it was August 10) I went to the clearing. I sat on the same old bowlder, waiting until it was so dark I could not see my notebook. Not a sound came from the three woods, except- 
ing the explosive barking of a red squirrel and the plaintive cry of the wood pewee. It became so lonely that I would have paid cash down for the merry, inquisitive chatter of one chick-a-dee. I was just ready to give up and start for home, when I caught coming from the depths of the woods a contralto phrase - certainly it was Dulcet's voice! This one phrase seemed to open his habit, for he flew to the edge of the woods below me and sang several phrases; then he flew to the tree nearest me, a large silver birch, and there, almost directly above my head, he sang, with a pause now and then, for more than a quarter of an hour. At the end of the song he flew to the ground and kept running among the ferns, repeating that peculiar chuck which one ornithologist has named the "call of migration." In the dark I followed this call as well as I could through the tangle, until I heard it sound as if the thrush had stopped behind a large brushheap. Here I made 
an experiment. As quietly as possible I made my way to the opposite side of the brush-heap. Several moments of absolute silence followed. I could not hear even the small rustle of the ferns in the night air. Suddenly the moon, almost full, which had just risen over Mount Cannon, poured a flood of silver light into the clearing, revealing Dulcet on a dead branch which reached out of the snarl over toward me. I could almost touch him. He was, apparently, as much astonished as I was, for he looked me straight in the face a moment or two, and then rapidly repeated his call five timeschuck! chuck! chuck! chuck! chuck! This emphatic speech concluded, he flew into the woods. I remained for a time without moving, feeling something I will not try to describe; then I looked out through the opening, across the fields, and there stood the mountains majestic in the moonlight, and I thought, "I am very glad that they do not migrate." 


\section{III}

\section{THE FLIGHT OF BIRDS}

\section{LITTLE GLIMPSES OF A LARGE MATTER}





\section{III}

\section{THE FLIGHT OF BIRDS}

\section{LITTLE GLIMPSES OF A LARGE MATTER}

M $\mathrm{Y}$ interest in the flight of birds be1 gan, years ago, while I was reading a remarkable book, The Reign of Law, by the Duke of Argyll. This book, published in 1866, has a chapter which contains a scientific discussion of the machinery of flight. One example used in this discussion is the swift, "a creature," as the author says, "whose wonderful and unceasing evolutions seem part of the happiness of summer, and of serene and lofty skies."

In this accidental manner the swift was fixed in my range of interest, but $I$ never actually saw a swift until my home came 
to be in "Drew Forest." There, in that veritable bird-refuge, were swifts by the hundred. At times, on the early edge of a fair summer night, when the wood thrushes were fluting their antiphonal vespers, the sky above the campus trees was thronged with these amazing birds, in their prodigious aerial performancenow gliding, with wings crescent-curved; now moving in daring slants, at constantly changing angles; now describing longsweeping and up-rising curves; now combining, perhaps a score together, in an intricate pattern of criss-cross weaving; and now dashing at one another, and missing collision and general smash-up by no visible margin whatever.

\section{Disposition}

Birds have a group disposition just as surely as men have a group temperament. There is as much temperamental difference between a bobolink and a bronzed 


\section{THE FLIGHT OF BIRDS 65}

grackle as there is between an Irishman and a Norwegian.

This bird disposition is manifested in things as far apart as call notes are from nest building, and not the least interesting of these things is the style of flight. Keeping within my own limited experience I can say, not that all birds express temperament in flying, but that some birds do so.

For example, take the red-headed woodpecker, "a blaze of white, steel-blue and scarlet." In disposition this bird is, as one naturalist has said, "distinctly bourgeois." Turn one of Matthew Arnold's "Philistines" into a bird and you would have precisely this efficient woodpecker. In any weather his practical motto is, "Business as usual." No hour is well spent which does not see an acorn saved and hammered into its hole, snugly. And this businesslike disposition is perfectly expressed in the Red-Head's flight. There are heavy movements and clumsy 
flappings of the wide wings, and yet how strong and competent the flying is! True, there is undulation, but its lines are not beautiful, and there is no real waste of either time or energy. In its own awkward fashion the woodpecker's flight is as direct and powerful as is the swift, flashing flight of the sharp-shinned hawk.

In contrast with this bourgeoisie, let us place that black and gold sprite of the extreme tree tops, that sunny optimist of the wide expanse, our American goldfinch. Perhaps you yourself have chanced to hear his blithe per-chico-o-ree, and quickly looked toward the sky and strained your eyes to follow his ecstatic flight? How careless as to goal, as to time, as to expenditure of force! And what undulations, what entirely different undulations now, what rhythmic waves of joyous motion, what a charming tonic of hilarity! The flight of an American goldfinch is the full expression of a happy nature. 


\section{THE FLIGHT OF BIRDS 67}

\section{Grace}

If by grace we narrowly mean that æsthetic charm which is revealed by lightness, suppleness, and ease, then (not forgetting the herring gull, and not forgetting the square-rigged ship under full sail) the most graceful moving object in existence is, I would affirm, a flying barn swallow.

I am remembering this very minute a certain old barn in New Hampshire. It has no color, excepting the stain from rain and snow. From dawn till dark the big doors are wide open, like the arms of mercy, and darting in and out are swallows - in the sunlight mere streaks of blue -rich, warm, glinting, purplish blue, with confused minor touches of white, salmon, and chestnut.

And the flight! What poet-naturalist ever did or could describe flying barn swallows? But even a small attempt is alluring. They skim, flying low over pasture and pond; then flying higher over the 
orchard, deftly avoiding the tops of the trees. They turn, suddenly, in any possible direction - up, down, right, left - and all of it is done as lightly, as airily, as thistle-down catches a whisper of the breeze. They swoop, and, like mischievous torments, just graze some living thing, say a dog or a cat, but, before the dog can snap or the cat can spring, the swallow is half way to Anywhere. They dally, actually dally with the wind-rise with the wind, ride upon the wind, toss about with the wind - then, in sudden challenge, they face the wind and master it, shooting along as straight and unhindered as an arrow speeding toward the mark.

And if you are only fortunate enough to see barn swallows feeding their young on the wing!-parent and chick close together, mounting higher and higher, little breast often against larger breast, short tail sometimes covered by forked-tail, heads almost touching, and every motion seeming to belong to the wide, splendid 


\section{THE FLIGHT OF BIRDS 69}

sky-if you are only fortunate enough to see all this, you will, for once, behold æsthetic grace incarnate.

\section{Dignity}

I once saw an eagle in flight. As the distance was great and the light deceptive, the markings were indeterminate, but it was either a bald eagle or a golden eagle. Most noticeable was the spread of the wings, reminding one of Shakespeare's "full wing'd eagle" in Cymbeline. Taking the wings alone, they expressed simply power. It was, doubtless, this power which the Negro preacher had in mind when he prayed for his hero, Gilbert Haven (dialect partly dropped): "Bless our Bishop! May he go through this world like a pigeon on de reings ob de eagle!"

In an eagle's flight, though, there is more than an exhibition of power. This eagle I saw was flying from one range of mountains to another range. It chanced 
also that he was flying from a bright space of sky toward a space which was already dark with the gathering night. This combination of things seemed to charge the bird's manner with a quality akin to solemnity. He was very quiet, as if bent on serious business, and this quiet was emphasized by the fact that a cohort of noisy, fussy little birds was constantly trying to hinder him. But not even once did the eagle deign to notice these insignificant creatures. With a kind of rhythmic gravity he moved on above the turmoil of their petty attack. I say moved, but his body was so firmly poised, away up there among the clouds, and his wingstrokes were so very, very slow, that he appeared to get on without movement. His progress I measured by calculation rather than by simple eyesight.

It was a great mountain scene, but the flying eagle filled it, dominated it with peculiar dignity - I would name it austere dignity in deliberate action. 


\section{THE FLIGH'T OF BIRDS 71}

\section{Romance}

The migration of birds is full, not only of mystery, but also of a picturesque strangeness which amounts to romance. In the romance there are several fascinating features, but the feature which moves me the most profoundly is the migratory journey itself, taken as a total with both its long distance and its continuous peril.

One May morning, in "Drew Forest," I heard a high-pitched bird-call, not quite a whistle. It sounded like the whisper note of the cedar waxwing, only raised to a higher power. Quietly I maneuvered nearer and soon I heard much more-a series of sibilant notes-tsit, tsit, tsit, tsit, $t$ sit, tsit-six of them, "cobweb thin and glassy clear," hesitatingly given, first crescendo and then diminuendo. Searching eagerly, I noticed a slight flurry in the thick foliage, and then, just behind a twist of leaves, I glimpsed a bobbing mite of a bird, five to six inches long. In a 
few minutes he flew into an old, dying hemlock, where he was plainly visible. His crown was black; his cheeks, white; his wings, with greenish edges and white bars; and his back, gray streaked with black. The markings were so clear that I easily placed the bird-it roas a blackpoll warbler. With the quick recognition a thrill of happy amazement went all through me. For this wee creature, with his funny little attempt at song, was known to me, long since, as a most daring traveler. As a matter of fact, he was stopping for breakfast in our "Drew Forest" on a most perilous journey, by land and by sea-a journey which began in South America and might end only in Alaska!

This statement is so extraordinary that I would better confirm it by scientific authority. W. W. Cooke (United States Biological Survey) says: "The shortest journey that any blackpoll performs is thirty-five hundred miles, while those that 


\section{THE FLIGHT OF BIRDS 73}

nest in Alaska have seven thousand miles to travel to their probable winter home in Brazil."

\section{Contrast}

"The Buzzard sails on,

And comes and is gone,

Stately and still,

Like a ship at sea."

In this fragment of Southern poetry there are noted four qualities which the turkey buzzard shows when on the wing: (1) Sailing. He sails through the air as truly as a ship sails over the water. (2) Instantaneousness. He "comes and is gone." Indeed, his appearance and disappearance are so instantaneous as to suggest the preter-natural. (3) Stateliness. Phases there are of the circular flying which are even majestic. (4) Stillness. Not quite the word, but the bird has what the artists call "repose in action."

But there is another, and a most significant quality too, which the poet has 
not caught. Buzzards "move up the sky," with upturned wings, in beautiful spirals of flight, these spirals becoming ever smaller, until the bird is but a small ink-stain on the zenith.

Here are surprising qualities, surely, but the turkey buzzard's peculiar appeal to the imagination lies, not in these qualities as separate items of flight, but in the total beauty of the flight as it appears in utter contrast with the ungainly form and bearing of the bird rohen not on the roing. In this buzzard contrast we have exactly the æsthetic principle which was creative of such wonderful effects in the oratory of Abraham Lincoln and in the conversation of Madame de Staël. Awkward bulk over against transcendent expression!

\section{To a Turkey Buzzard in Florida}

$O$ somber bird of name and deed unblessed!

Above the sand, I saw thee rise, and sail Aloft, with upturned wings, in spiral flight, Until the merest blur against the blueThat blue ineff able which hints of Italy. 


\section{THE FLIGHT OF BIRDS 75}

And thou didst teach me more than one is taught

By mockingbird, or plaintive pine-woods sparrow,

Or any singer of the famous choir Which fills the golden frame of Florida. For thou didst say to me, in occult speech, That any soul, with any unblessed task, Can find a way to rise above the sand And Spanish Bayonet, and reach the sky, And fellowship, at will, with things celestial. 



\section{IV}

\section{A PASSING WORD ABOUT TREES}





\section{IV}

\section{A PASSING WORD ABOUT TREES}

To a tree that has grown as God willed, we come without a theory, and with no botanical predilections, enjoying it simply and thankfully.-James Russell Lowell.

7 HE first time I ever saw "Drew

1 Forest," Doctor Upham, my gracious host, suddenly said, "Do you want to see the finest thing we have here?" Not waiting for an answer, he started in the direction of Cornell Library. This direction led me vaguely to expect to see a rare book, or an old manuscript, or a historic portrait. But, before we came to the library, the Doctor stopped, backed away from the path, and, with a quick flourish of his right hand and entire arm, as if try- 
ing to sweep the whole campus into the spot in front of him, exclaimed heartily: "There it is! That beech! Is there anywhere on earth any living thing more beautiful?"

\section{Tree-Individuality}

To me, though, the most striking thing about that noble beech, or about any notable tree, is not its beauty as a feature of the natural world, but, rather, its large quantity of individuality. In fact, I mean more than bare individuality, I mean individuality expressing type. Truly remarkable trees not only have an itemnic individuality, they not only hold their own as organic, significant, impressive items in the vast confusion of nature, but they gather up into most particular stress all the characteristics of the tree groups to which they belong. Just now I am remembering with keen delight a mighty oak which I found, perhaps two miles out from the city of Dresden. It was a red 
oak, at least one hundred and fifty feet high, and every part of the tree in generous correspondence. Looking at that giant of the forest, I seemed to behold all the oaks on earth, and all the oaks which ever existed, summed up with finality in one commanding oak-individuality. It reminds me of an amusing saying concerning our great Civil War minister at the Court of Saint James, "Charles Francis Adams was not one man, he was the whole Adams family in one man!"

This tree-individuality is, strangely enough, the one thing which many of our poets do not seem to be able to capture. They describe a tree in becoming and sure appreciation of its general features and associations, and, sometimes, with a quick sense of its accidental aspect; but they altogether miss the fundamental peculiarity of the type wonderfully and fascinatingly manifest in individuality. Sidney Lanier, in "Under the Cedarcroft Chestnut," writes in this manner: 
"Trim set in ancient sward, his manful bole Upbore his frontage largely toward the sky."

As I sit at my desk I catch glimpses, now and then, of several kinds of trees, and trees as far apart in family, genus and species as the American elm is from the scarlet maple; and yet Lanier's lines would in description answer well enough for every individual tree of the several kinds.

In a whim of inclination, I once read, at a single sitting, a large number of poems about trees, and, to my surprise, I found that in one poem only had the poet seized any real tree-type-individuality. This lone exception was the poem by Wordsworth called "Yew Trees," containing a description so extraordinary as to warrant emphatic consideration in this connection:

"There is a yew-tree, pride of Lorton Vale,

Which to this day stands single, in the midst of its own darkness. 


\section{TREES}

But worthier still of note

Are those fraternal Four of Borrowdale, Joined in one solemn and capacious grove; Huge trunks! - and each particular trunk a growth

Of intertwisted fibers serpentine Up-coiling, and inveterately convolvedNor uninformed with Phantasy, and looks That threaten the profane; - a pillared shade, Upon whose grassless floor of red-brown hue, By sheddings from the pining umbrage tinged Perennially - beneath whose sable roof Of boughs as if for festal purpose decked With unrejoicing berries-ghostly shapes May meet at noontide." ...

In this remarkable poem, Wordsworth has captured utterly the type expressed in tree-individuality; and he has done even more-he has saturated his description with the weird, solemn inner quality of the type. Who save William Wordsworth could have used the phrases "unrejoicing berries" and "in the midst of its oron darkness"? 


\section{Tree-Friendliness}

Another tree-quality is what one enthusiast has termed "their friendliness toward men." In any case, due probably to the combination of practical, æsthetic, and mystic features, trees, especially large and towering trees, make a powerful appeal to man's nature. They easily fit into his many moods. They influence him subtilely. They sometimes inspire him. They sometimes quiet his stormy heart. Only indirectly do they reach his moral personality, but they do have complete access to his total impersonal individuality. To a sensitive soul, a perfect tree is, in effect, much like a perfect symphony.

Beyond all this too there is between trees and certain men an indescribable reciprocity. There is an intricate cosmic entanglement. Thus certain men care for trees as instinctively as John Ruskin cared for the mountains. Plato was fond of great trees, and under them would walk and sit and meditate for hours. Xerxes 
held up his army that he might enjoy an Oriental plane tree, a tree probably more than a thousand years old. And it is recorded, "He had its form wrought upon a medal of gold to help him to remember it the rest of his life." Tolstoy, returning home and discovering that one of his special trees had been cut down, exclaimed: "It is nothing short of murder!" In one place in Walden, Henry David Thoreau says, "Instead of calling on some scholar, I paid many a visit to particular trees." Indeed, it is clear enough that there are men who come to regard particular trees in about the same affectional way that they regard their particular friends. John Muir, our famous Western naturalist, speaks of loving trees and living with them in profound intimacy. Referring to Muir's tree-experience, one sympathetic writer says, "Tree-friendships are very precious things."

An instance of this tree-friendship even more notable than that of John Muir I 
found while reading Tschudi's Life of Elizabeth of Austria. Here is a free but essential translation of the significant passage. In a rare moment of self-revelation Elizabeth says: "In Gödöllö I have a tree that is my best friend. As I reach Gödöllö, and just before I come away, I go to see this old tree. For some minutes we look at each other in silence. The old tree seems to know all there is inside my soul. And I dare to trust him with everything which has taken place in my life while we have been separated."

To understand this extremely pathetic passage, we need to remember that this most beautiful and most gifted and most sensitive woman was abnormally placed, in a salacious and artificial court, where she was in perpetual revolt. Also that, like the poet Heine, she was possessed by the demon of originality, and was, therefore, ready and eager to interpret the whole universe in a fashion all her own. Also that she was under the crushing 
weight of an unspeakable sorrow, and could get no help from the complicated and ingenious religiosity of the Roman Catholic Church, in which she had been brought up. To her, in this dreadful time, God, and even her Saviour, were "as dim as darkness itself." It is not beyond the truth to say that religiously considered she was utterly friendless and utterly alone.

Some years ago, at a period of my life when Wordsworth's poetry was to me almost such a tonic as it was to John Stuart Mill, I tried to appreciate and gather up into full poetic expression this intense tree-experience of Elizabeth of Austria. I wrote a little poem (later published in The Independent), in which I aimed to reproduce the delicate, mystic note of the lyric, "I wandered lonely as a cloud." Whether I achieved any small meed of success, I will leave to the decision of those, and only those, who still, in these garish days, care for the simple 
88

\section{THE MOUN'TAINS}

sincerity and "homely humanity" of William Wordsworth.

\section{The Friendship of a Tree}

There came a time when men were far, And Christ himself I could not see,

Then, like the creatures of the air, I found the friendship of a tree.

He stood there silent in his joy, He did not try to speak to me, And yet I knew, without a word, I had the friendship of a tree.

And now I meet him day by day; In rain and wind $I$ watch his glee; My restless sorrow builds a nest In mystic friendship with a tree. 


\section{V \\ IN AN OLD OLIVE GROVE}





\section{V \\ IN AN OLD OLIVE GROVE}

We must wander often and rest long in these ancient olive groves in order to become acquainted with the charms that are peculiar to the tree. The venerable trunks which have bestowed food and fuel upon generation after generation should be viewed in the diffused sunlight, with glimpses here and there of the deep Midland Sea.-Professor Flückiger.

T $\mathbf{N}$ any country or historic region it is 1 interesting to discover its physical emblem, that is, the outward sign which may fittingly be allowed to stand for the locality's peculiarity. Surely, a man is lacking in more than one quality if, in "brave little Holland," he can see without emotion a windmill at its tremendous task.

In Liguria a worthy physical emblem is furnished by the olive tree. It is the 
olive which maintains the supreme place in the scene, and which has the most comprehensive and the most practical relation to the actual life of the people. There are several kinds of olive oil which are used as food, and there are cheaper kinds which are used in many important industries; then the wood is used in making not only furniture, but also all sorts of artistic objects; then the branches and roots are used for fuel. In spite of the incoming of American petroleum, the olive tree would, some believe, more than hold its own if only it were jealously protected; but the Italian authorities, foolish beyond measure, allow the sneaking hunters to shoot, literally by the thousand, the song birds which are the natural guardians of the tree.

In October the fruit of the olive begins to ripen, turning first from green to plum purple, and then becoming almost black, but with a rich bloom. By December the harvest is on, and it continues for several 
months. Perhaps not so appealing as the grape-gathering along the Rhine, still the olive harvest makes a picture never to be forgotten. The peasant women (almost always with children helping or playing about) bending busily under the sunlit trees, or working their cautious way down the narrow and rocky paths, the bulging bags of fruit poised precisely upon their erect heads. Pretty touches are unconsciously added to the picture by bits of bright color in the dress, or by those quick Italian movements which are as graceful as long branches swaying in the breeze.

In good years the fruit is not allowed to drop dead ripe into the grass, but mats and cloths are widely spread beneath the branches, and the trees are lashed with poles which are as pliable as fishing rods. Wandering about in an olive grove, one often hears this lashing, with its continued rattling against the bark, followed by the soft hail of the dropping fruit; and, possi- 
bly, there may come to the ear now and again the sharp crack of a breaking bough when the peasant's stroke has been fierce or clumsy, or when the beating has been several times repeated. At such a moment one is apt to remember the kindly wise words in the book of Deuteronomy: "When thou beatest thine olive tree thou shalt not go over the boughs again: it shall be for the stranger, for the fatherless, and for the widow."

This very fruitful harvest, however, takes place only once in three years; according to one authority, only once in five years on the average in a long series of years. It would seem that in the time of Horace the crop was much more reliable, for he says, "There, the gray olive, year by year, yields its unfailing fruitage." Of course my knowledge of the matter is extremely superficial, but I have the surmise, if not the certainty, that the present unprofitable condition of olive culture in Liguria is due (beyond the slaughter of 


\section{AN OLIVE GROVE}

the insect-destroying birds) to the meager manner in which the trees are cared for. Without assistance the olive tree will exist; but without assistance, and much assistance, it will not repeatedly load its branches with fruit. Like several of our finest pippins, the olive demands generous nourishment and tenderest care. Its case comes thoroughly under the saying, "Much love, much service."

In a certain botanical treatise we read that "the olive is a useful tree, but devoid of beauty." How any student of the natural world could hold such an opinion passeth understanding. Readily we admit that the olive has not the ethereal beauty of the white birch, neither has it the balanced tangle in tracery of the beech, nor the exquisite uplift which has been called "the skywardness of the elm," nor the Gothic dignity of the spruce, nor the noble slenderness of the tallest palms, which in Oriental speech are "like the proud daughters of kings"; but the olive 
has one thing far beyond any of these trees-a profound mystery of glorified color. The olive leaf is thus described: shape, long and narrow, resembling the leaf of a willow; color, on the upper surface, dark and somewhat glossy green; on the under surface, dull silver gray. This description, though, does not convey even the smallest suggestion of what takes place when these leaves are combined in mass. A wonder takes place. Baring-Gould tries to express this wonder by comparing the effect to "smoke rising from a lowly cottage." The word "smoke" is excellent, but it does not do enough, and the word "rising" is entirely wrong. In "Aurora Leigh" Mrs. Browning captures almost the right phrase when she says, "The mystic floating gray of olive trees." Let us bring her line yet nearer to the wonder, by daring to borrow Baring-Gould's excellent word. The result is: "The mystic floating smoke of olive trees." Even now the wonder is not 
utterly in our grasp, for we have not in any degree expressed the witchery of the light in its ceaseless play throughout the mass of shape and color. I have watched an olive grove both in the moonlight and in the sunlight, and in every instance there was a transformation which was the most subtle work of color-glorification that I have ever seen in nature. Even among the poets it is probable that only one has ever lived who could convincingly express the evasive glory.

Under simple obligation to a wonderful experience, I should say one thing more. Two days ago I saw an olive grove, covering many acres, shining under a Riviera sun, with all the millions of leaves quivering and turning and lifting and dropping in a very strong wind. In effect it was like nothing so much as the weird passage in Grieg's music where the kings of the mountains are represented at their somber and tumultuous sport. The scene was almost too much to bear. I wanted to lay 
hold of that botanist and drag him to the place and say to him, "Is that 'devoid of beauty'?"

The peculiar appeal of the olive tree does not depend, however, so much upon its beauty as upon its individuality. Every individual tree has the most marked peculiarity, with which you can become acquainted almost as thoroughly as with the features of a man's face. What is more, this individuality does not come merely from size and native form, as is the case, say, with the gaunt skeleton of a fig tree. No. The individuality of an olive is largely produced by its strange manner of growth. This strange way of growing I will indicate as closely as can be made suitable for a popular description:

1. A young olive tree usually has a single trunk, which, at a relatively short but varying distance from the ground, divides into two or more primary branches.

2. Both the trunk and the primary 
branches often twist about in the most puzzling circuits and at the most queer angles, no two contortions being in the least alike. Recently I discovered a trunk so twisted that at a distance it looked, for all the world, like a huge boaconstrictor winding about a perfectly straight bole.

3. When the tree has attained a considerable age it is almost certain to begin to decay on the inside. This decay so weakens the fiber of the tree that the powerful roots, pushing out in opposite directions, for nourishment in the poor soil, actually pull the trunk until it splits. Thus are formed two segments, each one more or less decayed. After years of further decay, one or both of these segments may be split again by the tugging roots.

4. Now comes the well-nigh incredible story of the bark. Naturally we would expect that all this decaying and splitting would finally kill the tree. Not so at all. The bark grows around every segment, either completely or sufficiently to insure 
the circulation of the sap, and so keeps the rent tree alive. The result is that the original tree becomes two or more trees quite separate, excepting at the roots.

5. More wonderful yet, this tree-group is not only fruitful, but even so vital that the roots send out sprouts (twice I have found as many as six), and these sprouts in turn grow into trees belonging to the one tree-system.

6. In this astonishing way, one olive tree, instead of paying its expected tribute to death, overcomes decay and becomes an organic olive community as it were, not merely existing on, but living on, positively flourishing for centuries. Indeed, in the older groves to the north of Bordighera, it is nothing unusual to find a decayed and split tree which is as much as three hundred years old; and in Beaulieu there is one patriarch which, according to both naturalist and historian, is a thousand years old.

If I have succeeded in making clear this 


\section{AN OLIVE GROVE 101}

strange manner of growth, anyone should be able to understand why I have placed so much emphasis upon this growth as related to the olive tree's individuality. But I am hoping that still more has been accomplished-I am hoping that I have made possible the realization of the profoundest element in the appeal of the olive. This vital endurance through centuries of struggle; this gaining new life and reenforcement at the very beginning of death; this lifting up, over all the scars of rending and over all the marks of decay, a shining crown of leaves and fruitthis compelling evidence that a long, long conflict has ended in victory, moves the heart mightily. And still a further sentiment is aroused. The victory is not bare victory. Our feeling is not such as we have when looking, for instance, at Turner's "Old Téméraire" - the battered warship, after the last battle and the final victory, being towed toward the sunset and a quiet haven, thing of triumph, but 
now useless and pathetic. No, no, no. The old olive tree stands there under the sky, harvest-producing, harvest-crested, harvest-promising, a splendid hint of endless vitality-death swallowed up in everlasting life!

At this point I need help. Take the finest old apple orchard you ever saw and carry it to the shore of the sea; then hold it back from the edge of the water far enough to allow a narrow town to crawl in between, then lift up the grove about eight hundred feet, then build for it an amphitheater of hills and mountains, then bathe it with an atmosphere of most brilliant translucence, then arch it over with a sky often as delicately blue as a robin's egg, then tone down the almost overpowering situation by the ringing of church bells, by the calling of a shepherd among his sheep, by the cracking of a driver's whip, by the shrill voice of a street vender, by the pell-mell happiness of children just out of school and by the 


\section{AN OLIVE GROVE 103}

unending hammer strokes of a man breaking stone somewhere in the road belowdo all this, and you can begin to realize what my old olive grove is in fact and in sentiment.

Bordighera is half framed by hills, and on every one of these hills there is an olive grove; but this one grove (I call it the "Saracen Grove") is the most attractive. In several ways it can be reached, but usually I prefer a path which passes through a fringe of pine trees, fully as aromatic as are our balsam firs in the White Mountains. The largest of these pines is the stone pine (pinus pinea), but popularly named the "umbrella pine," because, as a certain humorist said, "It looks as much like an umbrella opened as the cypress looks like an umbrella closed." Without doubt it is this stone pine to which Wordsworth refers in the Italian sonnet, where he describes the tree in one poetic, etching stroke as - "like a clouda slender stem the tie that bound it to 
its native earth-poised high." And later in the sonnet Wordsworth declares that this one pine tree, in its cloudlike beauty and suggestions, "supplanted the whole majesty of Rome."

In the midst of this old olive grove rises a massive tower, which several of the guide books affirm to be Roman in origin. However this may be, it was used as a watch tower when Saracen pirates harassed the Ligurian coast after the main Saracen army had been nearly annihilated by Charles Martel at Poitiers. One reason why I most enjoy this particular grove is that the trees are so planted, terrace above terrace, as to afford many open spaces which fill with sunshine and so modify the chill and somberness which often belong to an olive grove. Besides, through these open spaces one can catch marvelous glimpses in every direction. To the east you can see the old town of Bordighera, sitting like a fortress on its rugged hill-above the wave-eaten and 


\section{AN OLIVE GROVE 105}

sharply jutting rocks of the cape, above the tiny oratory built, according to tradition, over the cave where Saint Ampeglio kindled his fire and taught the peasants how to till the soil-and above the dismantled and picturesque fort where once was fought a half-humorous and halfpathetic battle between Bordighera and Great Britain. Off toward France, you can follow the shore line of the Maritime Alps, one of the mountains pleasantly reminding us of the outline and coloring of our own Mount Lafayette. To the northwest there is a view which no less an artist than Charles Garnier, the French architect, considered, from its panoramic character, "one of the finest in the world." The panorama is of a long, narrow valley filled with flowers and plants, the multitudinous tints all chastened into harmony by a wide border of olive groves which extend for miles along the sides of the hills. The scene is accentuated by cypress trees which here and there thrust their 
sharp single points up into the sky. In this panoramic reach toward the higher Alps, there stand out, shining brightly under the glorious sun, three "rock villages"-Borghetto, so low down that it is almost in the basin of the valley; Vallebona, somewhat higher, with its slender church spire; and yet higher, on the very crest of a hill, Sasso, like a mediæval castle in solid appearance; and yet, as Garnier says, "seeming to float above the treetops in an ocean of verdure." Then, to the south, lying at your very feet is the new town of Bordighera, called "Borgo Marina," its hotels and villas half buried in gardens almost tropical; and beyond the town everywhere - toward Gibraltar, toward Genoa, out past Corsica and Sardinia toward Africa-everyrohere the indescribable Mediterranean. I say "indescribable," and I mean it, but I will dare to quote Giovanni Ruffini's words in Doctor Antonio. "In front lay the immensity of sea, smooth as glass, and rich with all 
the hues of a dove's neck, the bright green, the dark purple, the soft ultramarine, the deep blue of a blade of burnished steel, there glancing in the sun like diamonds, here rippling into a lacelike net of snowy foam."

There is yet another reason why this "Saracen Grove" is most attractive. It is so placed above the Mediterranean, and not too far above it as to command a long stretch of the irregular and mountainous coast line, and so make possible and fascinating what I will call the imaginative localization of history. As a man rests there under the ancient olive trees, he is sure to call up the great past in empire, or in art, or in literature; then he looks along the coast until he fixes upon a relative point; then he thinks: "Just over there they landed," or "Just over there he was born," or "Just over there it all took place." In this way you picture the past, reproduce person and scene, and fling your heart hotly out into the vast region 
of history. And there may come transcendent moments when the vastness of your historic reach seems to be augmented by the vastness of the sea, especially so when the blue space of water is enlarged as the horizon line is pushed back and back into vagueness by the sun-beaten track of molten silver. In such an experience the centuries drop away like falling waves, you feel a suggestion of the Infinite, and you know exactly what the poet meant by the expression, "The press of immensity's caress."

Of all these dramatic localizations, there is one picture which appears again and again. Indeed, I have never visited my old grove without seeing this particular picture. Southeast toward Spezia I fix the locality. The definite point is a hill a little behind and over the bay. On this hill there is a monastery-that of Santa Croce. At the outer gate of the monastery stands a dust-begrimed traveler. I can make out his thin, angular 
face, a veritable composite of the faces of Savonarola and John Wesley. A monk comes to the gate and speaks to the stranger: "What would you?" The stranger "answers not, but looks at the wall intently." The monk speaks more kindly: "Friend, what would you?" Breaking out of his abstraction, the traveler gazes into the monk's eyes and utters one word-"Peace."

This is Dante, the exile from Florence, trying to find some spot where he may be allowed to rest. Held fast by the pathetic figure, I follow the exile, step by step, along this Ligurian shore, the entire distance from Lerici to Turbia. The Aurelian way of the Romans has long since crumbled, and the Corniche road has not yet been made; and so Dante must use the mule path, narrow, rocky, and tortuous. This path I can just discern as it winds up and over the shoulder of Monte Nero. Now a form rises above the huge ledge, and the exile is silhouetted 
sharply against the sky. He stops, turns partly around, and looks toward Spezia and Florence. Then he becomes aware of the complex beauty of the immediate seene. In spite of his weariness, in spite of his loneliness, in spite of his spiritual agony, he is the poet now with every sense alert. Nothing escapes him. He notes the gathering lift of the waves before they strike the rocks, the rhythmic groaning of the bare-legged fishermen as they haul their boat through the swishing surf, the hawk sailing high and then hovering over his prey, the young men loudly singing at their work, higher up on the mountain side, the black-eyed girl leading a goat over the ledge, the nameless yellow flowers here and there, bravely growing in the scanty soil, the shifting of the light as a cloud passes over the mountain. Last of all he makes a careful calculation as to the precise angle of his ascent, and stores the fact away in his memory for comparative use in his immortal poem: 


\section{AN OLIVE GROVE 111}

.. "Meanwhile we had arrived

Far as the mountain foot, and there the rock Found of so steep ascent that nimblest steps To climb it had been vain. The most remote, Most wild, untrodden path, in all the tract 'Twixt Lerici and Turbia were to this A ladder easy and of access free." 



\section{VI}

TREETOPS IN WINTER 



\section{VI}

\section{TREETOPS IN WINTER}

TWHILE reading Emerson recently

I came across a happy surprise. Years before, I had, in some careless way, received the impression that Emerson, like many of the poets, was able to perceive only the severe side of winter, as when in "The Titmouse," for instance, he says:

"The frost king ties my fumbling feet, Sings in my ears, my hands are stones, Curdles the blood to the marble bones, Tugs at the heart-strings, numbs the sense, And hems in life with narrowing fence."

Surely, in any thought about Emerson, I could not forget that well-nigh perfect "Greek fragment" (as James Russell Lowell called it), "The Snow-Storm"; 
but that poem, with the "farmer's sighs" and the "sled and traveler stopped" and the "courier's feet delayed" and "all friends shut out," can hardly be considered inspiriting, even if the housemates do sit-

"Around the radiant fireplace, inclosed In a tumultuous privacy of storm."

But in the third chapter of Nature, Emerson writes in a very different vein. He says: "I please myself with the graces of the winter scenery, and believe that we are as much touched by it as by the genial influences of summer." It was, I confess, a relief to discover this appreciation of that side of winter which is as inspiriting as it is beautiful; for Emerson I deem one of the truest and most authoritative interpreters of the natural world, and I could never be altogether certain that my own extreme fondness for the winter scene might not be either the whimsey of a nature-tyro or a "survival" of my New England origin. 


\section{TREETOPS IN WIN'TER 117}

Not now, however, will I undertake a full defense of wild, splendid old winter, although Lowell's "Good Word for Winter" is enough to convince any fullblooded man that such a defense could be made. I wish merely to call attention to one of the "graces of the winter scenery," namely, treetops. Even in summer, treetops are (save in the horse-chestnut and other trees of lush beauty) the most beautiful tree parts; but, in our climate at least, it is in winter that the treetop reveals its most compelling charm. The reasons for this fact are two. (Perhaps there is a third reason.) In the first place, the climactic significance of the top fully appears only in relation to the whole structure of the tree, and with deciduous trees anyway, the entire wonder of the structure is apparent only in winter. In summer, the foliage more or less hides the fine architectural lines, precisely as epicurean flesh is sure to conceal the fine structural lines of a man's face. Further, 


\section{THE MOUN'TAINS}

I have lately observed that some of our evergreens more strikingly exhibit their structure in winter, especially when there is snow on the ground; but I am not yet prepared to enforce and utilize the point. The second reason is that in winter the branches and twigs, now bare and cleancut, stand out sharply against the sky in all their thrust, and crisscross, and minute tracery. As a man said of the spire of Antwerp cathedral, "It looks like Mechlin lace flung into the air." Few things in the wide world, indeed, are more delicately beautiful than a long sky-line of lacelike treetops; the entire line in high relief against the sky; and the sky itself having that soft, pervasive, ineffable winter color which I will try to suggest by calling it a bluish, winter-gray pearl. Then, to complete the scene, there should be (and is likely to be) a small cloud or two sailing high enough to give perfect accent to the immeasurable heavenly altitude. It is a time to drop all your prob- 
lems and passively yield to the mighty uplift. Look, gaze up over the treetops until your soul is transported into the boundless spaces. Stay there, rest there, until filled with awe and mayhap you feel as small and as insignificant as Immanuel Kant felt when trying to apprehend the glory of the night-sky. There is only one way easily and wholesomely to come back to earth, and that way is indicated in the 103d psalm: "For as the heaven is high above the earth, so great is his mercy toward them that fear him."

Another beautiful winter scene is made by treetops (elms or very tall oaks I prefer in this case) in a snowstorm-not a furious storm, "announced by all the trumpets of the sky," but a silent, longgathering storm. Accidentally some one looks out of the window and exclaims: Why! it is snowing!" The flakes are barely getting to the ground though. They linger and float and dally like irresponsible children on an errand. But wait 


\section{THE MOUN'TAINS}

an hour, yes, wait two hours - the scene has become a swift, riotous, multitudinous pell-mell. Now look at the tops of those elms! Notice how the numberless white sprites crazily confuse the network of outlines; notice the chaste flecking of the rough bark; notice how the color of the bark seems to get richer in tint, and how the tint tries to hold its own through all the whirl of the flurry; notice the complicated pattern of motion-its intricacy, its oddity, and its vitality; notice the throbbing play of the light in and through the upper branches; notice how sky and treetops gradually come together-how they weirdly blend just as they do in the gloaming. ... It is night now; the ragged remnants of the storm are drifting, "like shattered rigging from a fight at sea"; moon and stars are forcing their faces through in splendor; the treetops look weary and ghostly. . . Let us wait until the scene is motionless. ... A still winter midnight after a long storm! The 


\section{TREETOPS IN WINTER 121}

words we need are those of Robert Browning in "Paracelsus," where Festus says: "Best ope the casement: see,

The night, late strewn with clouds and flying stars,

Is blank and motionless: how peaceful sleep The treetops altogether!"

Our last scene is in that paradise of trees, "Drew Forest." The entire picture is beyond my courage; but here is a fragment: A group of white birches, and snowbesprinkled spruces standing over against the eastern sky. It is a December morning, perhaps ten minutes before sunrise. From where I stand, I now and then catch, through the treetops to the northeast, kindling patches on the distant, lowlying hills. Squarely in the east are long, streaming pennants of color-none regular, none gorgeous - just dull reds alternating with blues so dark that they barely escape being somber. The tops of the birches are the first to respond to the dawn, and very soon their plumes, droop- 
ing and gently swaying, shine like threads of silver filigree. But only for a few moments are the birches central in the scene, for the tops of the spruces now become aware of the rising sun. All their sharp points and variant angles are suddenly burnished, and over the dark green branches, powdered as with damp marble dust, there is a shimmer of gold beryl which seems to light up the erect dignity of the spruces with unmistakable gladness. You begin to appreciate those exultant words in Isaiah: "All the trees of the field shall clap their hands." For these transformed spruces appear to be ready to do any joyous thing!

I break away from the small group and look over the whole sweep of the forest, and everywhere it is morning in the treetops. 
VII

\section{JOHN}





\section{VII \\ JOHN}

A FEW days ago death came to an A old Negro- "John"-who for many years had worked on the grounds of Drew Seminary. Since his death, to relieve the emptiness of the scene, I have been reconsidering my previous partial estimate; and this morning I surprised myself with the conclusion that, of all the humble people I have known, this obscure Negro had the most pristine and almost the most interesting individuality. The material should be treated by an interpreter of human, nature having a particular gift for understanding and portraying inarticulate and unlabeled manhood; such an interpreter as Turgenieff, or Bret Harte, or the author of immortal "Marse Chan." But, as no such interpreter is available, I will 


\section{6

do what I can to hold back an extraordinary character from the inequity of temporal oblivion.

The outward thing which appealed to me when I first met John, twelve years and more ago, was the directness of his face. I do not mean facial sincerity, that expression of moral genuineness which ennobled the face of John Jasper. Neither do I mean that expression of personal frankness which was no small part of the fascination of Booker T. Washington's face, one of the three most powerful faces of modern times. I mean no moral or personal thing whatsoever, but merely that immediateness, or nakedness if you will, with which nature sometimes reveals an unmitigated reality. For example, note the sheer bareness of a crag when the whole mass, with every jut and fissure, stands exposed without even a softening shadow. John's face was like that. It gave out directly, nakedly, all the meaning he had. 
As he neared the end, a look of weary waiting, such as may be seen in the eyes of a tired ox, appeared in John's face, and remained there for days at a time. This peculiar look, together with his broken form and dragging movement, emphasized the mien of old age. How old he really was I do not know; I could not accept any of the flying statements; but, whatever his actual age, he certainly was, at the last, the oldest-looking man I ever saw. His aspect instantly brought to mind Faber's pathetic "Old Laborer"; or, even more fittingly, that stanza which in the Negro song describes the debility of old age with a touching realism worthy of Paul Laurence Dunbar:

"His fingers were long like the cane in the brake,

His eyes were bad for to see,

He had no teeth for to eat the corn cake,

So he had to let the corn cake be."

And yet it was precisely this decrepitude which furnished an effective back- 
ground for John's bearing of innate dignity. One of our American essayists, probably Emerson, refers wonderingly to the exquisite dignity with which a wellbred woman crosses a muddy street. In much more awkward situations, I have watched John carry his twisted wreck of a body with the instinctive dignity which belongs to a king. Indeed, it has flashed through my mind that there might be lingering in John's veins an inherited trace of the blood of a chieftain who centuries ago ruled an African tribe. The most singular thing, though, pertaining to this bearing of dignity was that it was a visible conquest over many ungainly physical features. What Abraham Lincoln did in a large way $\mathrm{J}$ ohn did in a much smaller way, namely, he penetrated and dominated his entire body with a supremely independent spirit. John was reputed to be "queer" or "cranky," and it is not surprising, for he was as rigidly independent as is a red oak in a hailstorm. 
Sometimes his opinions were slenderly related to fact, but never were they borrowed. A notion his very own he had of every teacher, every student, and every important thing that touched his daily life. Extremely noticeable was this independence when he accepted money, or a gift of any sort. Once, in Germany, I gave a mark to a prosperous tailor, and he smiled and bowed and gesticulated until I was almost prone to think that unwittingly I had saved his life. No touch of such servility was in John's nature. He was quick to manifest gratitude; but he had a manner of closing the whole transaction by looking up and away over the treetops, as if he had an understanding with the sky, that only accidentally was he a recipient.

John was not a typical servant. Not that he was unfaithful (he was the full opposite of that), but he required an ample margin of liberty. He could not be driven; he hated to be urged, and no dic- 


\section{THE MOUNTAINS}

tator could fruitfully manage him. Furthermore, he had an intense pride in his province, and seriously objected to the surrender of any of his traditional rights. One fall he was so late in beginning to clip the hedge that I engaged another Negro to help at my end, innocently supposing that John would be delighted with the arrangement. I was soon disabused, for he dropped his shears and excitedly exclaimed: "I kin do it all without him, or he kin do it all without me." If, however, the margin of liberty was duly granted, John would charge his work with devotion and delight. Again and again I have discovered him working far beyond the agreement and far beyond the need, and this too even in wild weather. In this respect he was worthy of comradeship with Adam Bede himself, who said: "I hate to see a man's arms drop down as if he was shot, before the clock's fairly struck, just as if he'd never a bit o' pride and delight in's work. The very grind- 
stone 'ull go on turning a bit after you loose it."

Two of John's traits are of exceptional interest to every painstaking student of the naiveté of unsophisticated human nature.

1. In addressing any person whom hes revered John was indirect, sometimes even speaking as if the person addressed were not present, and the speaker's aim were to find out something concerning the absent person. Not like this: "Doctor, were you satisfied with what I did?" but roundabout something like this: "What did the Doctor say? Was he satisfied with what I did?"

2. To all forces and living things in nature, John was wont to ascribe gender, and to do this under an exact scheme of gradation. For example, a shrub (although as beautiful as a Japanese quince aflame with bloom) he regarded as only " $i t$ "; but a wind was " $h e$," and a tree was "she." In this connection I recall a quaint 
instance. A valuable hemlock seemed to be slowly dying, and I asked John for his opinion. He said: "I have watched that tree ever sence 'way back when Dr. Crooks lived here; and off and on she's acted just so ondecided. It's 'bout time she made up her mind what she's goin' to do."

Quaintness in John was deeper than the whimsical turn of speech, it was part and parcel of his very conception of things. He saw everything in odd relation or odd proportion. Usually the quaintness alone was sufficient to empty his mood, but when quaintness was not enough, he would burst into a gust of delicious humor. Here is an instance which fortunately $I$ have saved, but it must not be thought that in this, or in any other instance, I have entirely succeeded in preserving the dialect in every peculiarity of phrase and pronunciation. To do that would be a task almost beyond George W. Cable himself. In the "Old Mansion," while 
hanging a picture, I suddenly fell from the top of the step ladder, bringing down with me both ladder and picture in one general crash. At this, John began to laugh immoderately. Somewhat rasped, I snapped out: "And what is there to laugh at so?"

Half choking, John replied, "'Twas chiefly exciting when the Doctor did not stay up there as long as he intended."

In considering John's character from the standpoint of moral demand, two extremes should be avoided. On the one side, we should not assert or intimate that he satisfied, or even approximately met, the requirements of righteousness. Always it does harm so to glorify a few splendid items of conduct as to obscure the rigid fact that God's law demands a total, and never is content with a fragment. And it does as much harm to obscure Christian requirement; to say, for example, that a man is "practically a Christian" when he has never repented 


\section{THE MOUN'TAINS}

of his sins or accepted Christ as his Saviour. Furthermore, John was obstinate in spiritual things. Real Christian effort was made in his behalf, but he stubbornly avoided every opportunity to find the living way.

On the other hand, we should not assume that we ourselves understand absolutely a man's hidden life in its profoundest relation to the Holy Spirit. Now and then there may be abnormal cases which cannot be tested by our typical, finite standards. Moreover, as Christian men we should be ready to appreciate any discoverable atom of manifest loyalty to a moral ideal. A bit of gold dust is not enough, surely, to make a coin of the realm, but it is gold dust, and not the sawdust of a buttonwood tree. I will not say that John Nicholls is a John Wesley because, as a sheriff, he saved from a lawless mob a Negro in his custody; but I will say, and I ought to say, that the sheriff is a brave man. If anyone wishes to find 


\section{JOHN}

135

a Scripture basis for this attitude, he can find it in the tenth verse of the second chapter of Saint Paul's Epistle to the Romans.

John, in addition to the faithfulness already noted, had two traits which morally are pure gold. The first of these was his quick regard for equity. Not justice; it was several degrees finer than isolated justice. For example this: Before going away on my vacation on one occasion, I offered John the opportunity to earn some extra money by splitting up several hardwood logs. On my return I found the logs untouched and asked John why he had not done the work. His answer was: "I wanted the money,

'lowed he had charge of that woodshed, and I feared I'd no fair privilege to take his job."

The other moral trait was generosity in burden-bearing, a trait which may involve unselfishness itself. For example this: Four men, including John, were 
laboring to carry a piano upstairs. At one point the way was circuitous and it seemed impossible to go further. Out of breath, and out of patience, the regular piano movers gave up and were about to begin to work their way back to the first floor, when John, already half crushed against the wall, shouted out in his highkeyed voice: "We kin do it, if you but 'low the heft to come more right down on me."

One more quality there is which I must notice, but shrink from trying to place or estimate. It is better simply to state the fact, and allow everyone to think of it as he will. We tried to get John to attend Dr. Upham's funeral, or at least to go into the chapel after the funeral and look at the body, lying in state, guarded by the students who loved their teacherfriend. John would not go; but he did go to the extreme limit of the seminary grounds, and there, bareheaded, his old rake in his hands, he stood silently, like 
a soldier at attention, as the procession passed through the front gateway and down the village street. Of all the tributes to Dr. Upham, this one of John's seemed to me to be the most beautiful. The next day I asked him why he would not go into the chapel. Very slowly and timidly he said: "I did not want to see Dr. Upham look like that, I want always to remember him as I used to see him going about."

In closing this character-sketch I wish to pass beyond my own estimate, and to quote the words of a man who for many years was close to John in daily association, a man of large charity and yet never inclined to weaken either a Christian doctrine or a Christian demand. After John's death, this man said: "This morning I have been thinking of John. He did not know much about the Lord, but I believe that he did live up to his light." 



\section{VIII}

\section{THE ILLUMINATION OF AN OLD FARM}





\section{VIII}

\section{THE ILLUMINATION OF AN OLD FARM}

NOT long ago, out there somewhere in the vast upper spaces of mystery, our Lord welcomed into his peaceful presence a man whom he was ready to glorify. Here on the earth this man was called James B. Doolittle; but the name was a misnomer, for in any kingdom of equity he surely would have been named Do-much.

\section{"A Conspiracy of Friendship"}

When, as a boy, I first met this man, he was a farmer, living a few miles from one of the most beautiful of our midWestern villages, Delavan, Wisconsin. Rudyard Kipling is, as far as I now recall the writers, the only one who has 


\section{2 \\ THE MOUN'TAINS}

grasped and perfectly expressed a boy's elusive nature, and it is folly for me to try. This much, though, I need to say: although only about twelve years old, at once I understood this farmer, at once I pierced the clumsy disguise and discovered the real Bayard. Yet more strange, perhaps, he instantly seemed peculiarly to care for me. And thus, there and then, began a "swift conspiracy of friendship" between a man and a boy.

As an outcome of this friendship, the "old Doolittle farm" became to me a kind of home extraordinary. To this home, at every twist and turn of things, I managed to hasten, staying for days, or weeks, or even months at a time. In the farmhouse, Mrs. Doolittle (who soon joined our conspiracy) gave me, "for my very own," a room and allowed me to carry out all my whims in arrangement. As I write, this room comes out clear-cut in memory: the low angle-broken ceiling; the cramped, rattling windows; the oak- 
stained and heavily varnished furniture, "bought in Milwaukee"; the rag rugs, oval in shape, and somewhat humpy in places where the turns had been too quickly made; and on the wall, overwhelming the "family portraits," and commanding the whole room, a monster worsted watch pocket, having an intense grass-green background, and fronted with roses, puffed out like inflated cheeks, and as richly flaming as the body of a scarlet tanager.

In this room I kept some of my books; in this room I studied, in this room I dreamed a lad's dreams; in this room I "threatened to do something in the world"; yes, and later, in this little room I prepared (surely the word needs italics) my first sermon.

\section{A Chapter in Democracy}

This old farm I want, if I can muster the gifts, so to illuminate as to make apparent some of its fine characteristics. 


\section{THE MOUN'TAINS}

The task merits the genius of John Millington Synge.

"He loves the open air, the reinless run

Of wind and star; he loves the flying clouds; He goes companioned of the kindly sun,

Erect, with head unbowed."

This stanza from "The Westerner," a noble poem by Edward Wilbur Mason, I quote because it exactly reminds me of the spirit of "Doolittle Farm." You felt there the independent simplicity of a strong life in close and sensitive relations with the primary cosmic forces. In my bias of imagination, it often seemed to me that the horses on the farm and all the cattle even, showed an independent individuality quite unusual with such creatures. In any case, they all were so treated as to bring out the best innate qualities. Then, as is the fact with many a Western farm, the general bearing of the place was aggressive. A bit of contrast here may help to make plain my meaning. A typical New England farm 
is protective and defensive. The whole combination has the air of a fortification. The house is joined to the woodshed and the woodshed is joined to the barn. And so the farmer can do his "chores" and much other work snugly protected from cold and storm. By changing one line he could adopt the classic song:

"Then come the wild weather,

Come sleet or come snow,

We're safe under cover,

However it blow."

But the Westerner is not so protected. He must take more chances with nature, and so he may gain more pliability and daring, and possibly, develop the capacity to deal with things on a larger scale and with originality.

In those priceless Journals, now slowly coming from the Riverside Press, Emerson refers to a Western hotel where, on the wall of the dining room, there was this notice: "No Gentleman Permitted to Sit at the Table Without His Coat." Of 


\section{THE MOUNTAINS}

course, one quickly feels the deliciously unconscious humor of this notice, and the humor is even richer over against the Brahmanic dignity of "the Concord seer." Just imagine Ralph Waldo Emerson walking into that dining room and reading that notice! But what I fail to understand is that there is any essential difference between this country-shirt-sleeve comfort and all those tolerated sorts of negligee which, on any hot summer day, one can find at the Polo Grounds, or in a Wall Street office, or even in many a metropolitan restaurant. But to use the Irish privilege and "drop the dispute before it begins," I will content myself by declaring that nothing finer have I ever seen than a coatless dinner, in harvest time, with James Doolittle at the loaded table and all his "farm hands" about him. No skill of mine is sufficient fully to reveal the open hospitality, the half-concealed courtesy, the quick generosity, the spontaneous heartiness, the human funda- 
mentalness of it all. It was a complete chapter in intrinsic democracy. The manners were democratic, the conversation was democratic, the very "soul of the feast" was democratic. Never was it in any way apparent that one man owned the farm and the other men worked for wages. James Doolittle was simply the perfect host and these sunburned fellows were ravenously hungry. "Billy, your plate begins to look empty again." After all the years the words are still charged with comradeship!

Thinking of harvest time there comes to my mind another scene. "Hands" were "short," and I was trying to help out by driving a team. Unfortunately, we went too near a nest of bumblebees. They stung the horses and came at me. I lost control, the machine struck a stump and canted over, the driver was flung sprawling. James Doolittle was on hand, as he was ever on hand, and his laughter sounded out louder than the whistle of 
the meadowlarks. He had no lofty notion of college education, and, in his own quiet, kindly manner, he rather enjoyed any harmless evidence of my practical inefficiency, but in this one instance his enjoyment was almost rollicking, for the situation appealed to all his latent sense of humor. Indeed, the scene, especially the ensemble, was extremely comical (afterward he described it with gusto), the bees so very small and so furiously triumphant, the big mower so instantly and so queerly upcanted, the horses so wildly plunging, and the terrified driver thrusting a dirtflecked face up out of the tangle of crumpled grass.

\section{Pure Religion}

The religious life of "Doolittle Farm" was rooted in moral integrity. With the utmost emphasis it should be said that the place was morally sound even in little things. Visiting the farm again and again, for more than twenty years, I 
never heard a false word spoken. And I never discovered any sly schemes to render small deceptions inevitable to some one. Life on that old farm was as frankly open to all concerned as a great prairie is open to all the winds. Nor was there any "trick within the law," such as is sometimes used in country trading. James Doolittle was not a David Harum. He was not "all-fired keen at a bargain." Not easily could he be fooled himself, but he had no ambition, in a tussle of wits, to win by cheating the other man.

In Wisconsin I once saw a patch of delicate columbines growing on the sheer face of a ragged cliff. James Doolittle and that Wisconsin cliff are in my mind together, for his rugged character was adorned by the most delicately beautiful thing belonging to the religious life, that is, reverence. On his farm no cheap trifling with sacred things was countenanced. He did not make Christ an easy commodity for pious phrases either. Our 


\section{THE MOUNTAINS}

Lord he followed in confidence without undue familiarity.

The patch of columbines on the cliff was most beautiful at family prayers. James Doolittle's reading of the Bible was peculiarly redolent of reverence. No artificial emphasis, no dramatic declamation, no "religious tone"-just a real man with his natural voice paying to God an eager tribute of quiet reverence. And when the prayer came-so direct, so homely, so believing, so evidently sincere -we felt as if the old farm itself had suddenly taken on the bright shining of translation.

"Compared with this, how poor Religion's pride,

In all the pomp of method, and of art, When men display to congregations wide

Devotion's ev'ry grace, except the heart!"

This reverent religious life, which began in moral integrity, culminated at last in Christian courage. I am now come to a place where my heart will not allow me to furnish the exact details. Enough to 


\section{AN OLD FARM}

say that when the dreadful test came, James Doolittle did not flinch. His Saviour he trusted absolutely. Hearing that the old farm had been sold, and that he was living alone in a small cottage in the village, I went to see him, dreading, I must confess, to meet the man after all the sad changes. But, save on the surface, he had not changed. Always a man of few words, he very soon said: "I want to show you my garden." At the sight of that garden I was simply overcome. Nowhere, except in Holland, had I ever beheld such a wonder of patient, loving economy. Every foot of space behind the house had been put to use. Not only was there every feasible kind of vegetable, but also there were flowers and flowers. In fact, all the dear old farm flowers were there, repeated as by magic-marigolds, border pinks, bachelors' buttons, sweet William, hollyhocks, and even sunflowers blazing against the shed. As I did not speak, he looked at me curiously and said: 
"What is the matter with you?" I could only answer: "I did not expect to find anything like this." Then his eyes filled, not with tears, but with light, and very quietly he said, "I will not let my little yard grow up to weeds just because I no longer have the old farm."

His words later yielded a sermon in me, and I preached it from this text: "Strengthen the things which remain that are ready to die." 




$$
35
$$


